\title{
Sikap Siswa Reguler Terhadap Siswa Berkebutuhan Khusus Dan Kecenderungan Bullying Di Kelas Inklusi
}

\author{
Uswatun Hasanah \\ Ni'matuzahroh \\ Yuni Nurhamida
}

Fakultas Psikologi, Universitas Muhammadiyah Malang, Malang

Email: nimatuzahroh7@gmail.com

\begin{abstract}
Abstrak
Sikap merupakan kecenderungan untuk bertingkahlaku baik positif maupun negatif terhadap objek yang disikapi. Pada pendidikan inklusi siswa reguler diharapkan menerima perbedaan yang dimiliki siswa berkebutuhan khusus. Siswa reguler dengan sikap negatif terhadap siswa berkebutuhan khusus akan memunculkan perilaku meremehkan dan pengucilan sampai menimbulkan kecenderungan bullying. Tujuan penelitian untuk mengetahui hubungan antara sikap siswa reguler terhadap siswa berkebutuhan khusus dengan kecenderungan bullying. Desain penelitian adalah kuantitatif korelasional dengan jumlah 200 subjek siswa reguler sekolah inklusi tingkat SMP. Skala yang digunakan adalah skala sikap siswa reguler terhadap siswa berkebutuhan khusus dan skala kecenderungan bullying. Hasil penelitian menunjukkan adanya hubungan negatif antara sikap siswa siswa reguler terhadap siswa berkebutuhan khusus dengan kecenderungan bullying yaitu ( $r=-0.234 ; p=0.000 ; p<0.01)$. Semakin negatif sikap siswa reguler terhadap siswa berkebutuhan khusus maka semakin tinggi kecenderungan perilaku bullying begitupun sebaliknya.
\end{abstract}

Kata kunci: bullying, inklusi, siswa sekolah, siswa reguler, siswa berkebutuhan khusus

\section{Pendahuluan}

Bullying merupakan tindakan menyakiti berupa kekerasan secara fisik, verbal, maupun psikis yang dilakukan secara terencana oleh pihak yang lebih memiliki kuasa terhadap pihak yang lebih lemah. Wiyani (2012) menjelaskan bahwa fenomena bullying bisa terjadi di mana saja, selama ada interaksi sosial yang terjadi, di antaranya adalah bullying yang terjadi di sekolah disebut sebagai school bullying, bullying di tempat kerja disebut sebagai workplace bullying, bullying dengan media internet disebut cyber-bullying, bullying yang terjadi di politik disebut political bullying dan bullying yang terjadi di lingkungan militer disebut military bullying.

Sejak tahun 1970 penelitian bullying ini telah dilakukan di Eropa dan sejak saat itu pula kasus bullying ini menjadi perhatian penting dalam dunia pendidikan maupun lingkungan masyarakat. Di antara kasus kekerasan yang telah terjadi dalam lingkungan pendidikan adalah kasus yang terjadi di Jakarta International School (JIS), yaitu kekerasan seksual yang dilakukan oleh 5 orang tersangka yaitu petugas kebersihan dan guru JIS yang membawa dampak trauma secara psikologis bagi korbannya, AK 6 tahun (Metronews, 2014). Selain kasus kekerasan yang terjadi di Jakarta International School, terdapat juga kasus kekerasan yang dilakukan oleh siswa-siswi SD di daerah Bukittinggi Sumatera Barat yang melakukan tindak kekerasan berupa pemukulan dan tendangan kepada temannya secara bergantian (Web.KPAI, 2014).

Menurut Pellegrini dan Bartini (2000) bullying yang terjadi di sekolah sering dilakukan pada masa remaja yaitu terjadi antar teman sebaya atau peer grup. Survei yang dilakukan oleh 
KPAI (Komisi Perlindungan Anak Indonesia) bulan April tahun 2012 menemukan bahwa 87,6\% mengalami kekerasan dalam bentuk siksaan mental yaitu kekerasan secara psikologis, dan juga berupa siksaan fisik. Selain itu bentuk kekerasan name calling dan pemukulan juga dilakukan pelaku bullying terhadap korban, dengan rincian $42.1 \%$ kekerasan dilakukan oleh teman sebaya, 29.9\% dilakukan oleh guru dan staf sekolah dan $28 \%$ dilakukan oleh petugas kebersihan sekolah dan keamanan sekolah. Survei ini dilakukan pada 1.026 orang responden. Dari tahun 2011 sampai 2014 tercatat ada 369 kasus terkait masalah bullying, sehingga dari 1.480 kasus ada sebanyak 25\% kasus bullying dari kasus-kasus lainnya (Web.KPAI, 2014). Selain itu, penelitian yang pernah dilakukan oleh Amy Huneck pakar intervensi permasalahan bullying dari Amerika Serikat, menemukan bahwa 10-16\% siswa Indonesia menerima perilaku dalam kategori bullying, yaitu penghinaan dan ejekan kata-kata yang kurang mengenakkan, selain perilaku menyisihkan dari lingkungan sosialnya, kekerasan dengan cara dipukuli dan ditendang dan juga didorong (Wiyani, 2012)

Bullying ini ditimbulkan oleh beberapa faktor, yaitu faktor situasional dan faktor personal, dalam hal ini dijelaskan oleh teori General Aggression Model (GAM) oleh Anderson (2011). Anderson (2011) juga menjelaskan bahwa agresi disebabkan oleh banyak faktor yang terkumpul menjadi satu sehingga tercipta suatu persepsi yang kemudian dimaknai berdasarkan sikap. Setelah itu individu akan mengkaitkan apa yang didapat dengan keadaan sosial saat itu sehingga terbentuk tingkah laku agresi. Faktor-faktor situasional yang menjadi pemicu terjadinya perilaku agresi antara lain budaya atau iklim sekolah yaitu bullying yang dilakukan oleh guru atau murid, selain faktor perkembangan teknologi, dan norma yaitu nilai dalam suatu kelompok. Sedangkan faktor personal, dibuktikan dalam penelitian yang dilakukan oleh Muslim (2012), ditemukan bahwa remaja dengan kepribadian ekstrovert menunjukkan perilaku bullying lebih tinggi dibandingkan dengan remaja dengan kepribadian introvert.

Durand et.al. (2013) dan Borowsky et.al (2013) menerangkan bahwa dampak besar bagi korban bullying adalah pada mental dan kesehatan fisiknya, yaitu depresi, rasa cemas yang berlebihan, pemikiran untuk bunuh diri hingga percobaan untuk melakukan bunuh diri. Selain itu, Rigby et.al (2004) juga menjelaskan dampak rendahnya self-esteem korban, hilangnya rasa kepercayaan terhadap apapun, psychomatic symtoms, dan menghindari sekolah. Peran guru dalam permasalahan ini sudah pasti sangat berpengaruh, namun dalam studi Rigby (1996) (Ruggieri et.al.,2013) ditemukan bahwa 30\% guru tidak tertarik dan hanya sesekali akan menghentikan bullying.

Fenomena tentang bullying banyak mendapat perhatian dari para peneliti yang lebih memfokuskan pada perkembangan anak yang mendapat bullying di sekolah reguler. Namun kenyataan di lapangan menunjukkan bullying tidak hanya terjadi pada sekolah dengan siswa reguler, melainkan juga terjadi pada sekolah inklusi. Dari sana peneliti tertarik untuk melakukan penelitian terkait bullying di kelas inklusi. Di tegaskan oleh Adriana S. Giananjar, seorang psikolog dan pendiri sekolah autis "MANDIGA" bahwa selain masalah persiapan pendidikan, masalah anak autis menjadi korban bullying juga menjadi persoalan yang serius, karena menurutnya anak normal banyak yang menjadi korban bullying apalagi anak dengan kebutuhan khusus (Segiempat, 2014).

Pendidikan di Indonesia yang telah diatur dalam dalam undang-undang Republik Indonesia Nomor 23/ 2002 menyebutkan bahwa setiap anak yang tinggal, tumbuh, mendapat perlindungan dari diskriminasi, status sosial atau dalam berbagai keadaan (Yuniardi, 2011). Terkait definisi pendidikan inklusif, menurut Ashman dkk (Woodcock et.al., 2012), inklusi adalah mengenai sesuatu yang bersifat pribadi, yang dimasukkan atau ditempatkan dalam suatu kelompok tertentu untuk dapat memiliki hak dan kualitas yang sama. Ini berarti bahwa sekolah 
inklusi merupakan wadah bagi siswa dengan keistimewaannya atau anak berkebutuhan khusus untuk dapat belajar bersama siswa reguler.

Dalam penelitiannya Woodcock et.al. (2012) diketahui bahwa sekolah inklusi memiliki banyak kelemahan-kelemahan di antaranya adalah guru menunjukkan kekhawatiran karena ketidaksiapan SDM sehingga tidak banyak guru yang peduli terhadap anak berkebutuhan khusus. Selain itu standar akademik yang diterapkan kurang memadai, permasalahan di tempat kerja, dan masalah penerimaan terhadap anak berkebutuhan khusus. Pada penelitian Salend (Salim, 2013) mengenai keefektifan sekolah dengan program inklusi, diketahui bahwa selain keuntungan karena siswa berekebutuhan khusus dapat berinteraksi langsung dengan siswa reguler, hasil buruk juga didapat, yaitu isolasi dan frustrasi yang dialami oleh siswa. Keterbatasan dan keistimewaan siswa reguler dalam kelas inklusi menjadikan siswa berkebutuhan khusus rentan mendapatkan bullying dari teman-temannya yang normal, terlebih anak berkebutuhan khusus tidak memahami bahwa bullying adalah sesuatu yang buruk dan posisi diri ABK yang menjadi korban tidak disadari. Hal inilah yang menjadikan siswa reguler melakukan bullying kepada anak berkebutuhan khusus di kelas inklusi.

Salah satu kasus bullying yang terjadi pada anak berkebutuhan khusus di kelas inklusi adalah pada sebuah sekolah menengah pertama daerah Kalimantan Selatan memperlihatkan bahwa kelas inklusi yang menghadirkan siswa berkebutuhan khusus menjadikan siswa reguler melakukan hal-hal yang tidak sepantasnya dilakukan oleh seorang siswa sekolah menengah pertama, yaitu seperti mengolok-olok siswa berkebutuhan khusus dan ejekan lainnya. Bullying tidak hanya dilihat secara fisik saja melainkan juga secara verbal dikerenakan bullying secara verbal akan lebih menyakitkan dengan adanya sikap kurang menghargai sehingga mengejek dengan kata-kata yang kurang pantas dan tertawaan yang menyakitkan. Hal ini bukan hanya siswa yang melakukannya melainkan guru juga terkadang yang memulai melakukan sindiran terhadap murid ABK nya dengan menganggap bahwa ABK adalah gila (pokja-inklusifkalsel, 2012).

Trisnadi, seorang Project Manager Save The Children (Suara.com, 2014), menyatakan bahwa stigma negatif tentang anak berkebutuhan khusus masih melekat, yaitu ketika orang tua siswa reguler mengetahui sekolah mereka menerima anak berkebutuhan khusus, orang tua akan menarik anaknya keluar dengan alasan takut tertular. Hal ini menjadikan siswa berkebutuhan khusus menjadi terisolasi. Rigby et.al. (2004) mengungkapkan bahwa ada beberapa faktor yang mempengaruhi bullying, yaitu faktor kepribadian dari masing-masing individu, latar belakang keluarga, cacat secara physical dan pengaruh dari pertemanan atau peer group.

Bullying dan beberapa variabel yang mempengaruhinya telah mendapat perhatian dari beberapa Negara dengan melakukan pengujian secara ilmiah dan telah menemukan adanya beberapa faktor yang mempengaruhi bullying baik pada perkembangan fisik maupun pada perkembangan kesehatan mental. Hal ini juga memungkinkan adanya beberapa variabel yang mempengaruhi bullying. Beberapa studi mengidentifikasi beberapa variabel umum yang berpengaruh besar pada bullying, yaitu kepribadian individu, komunikasi keluarga, teman sebaya dan lingkungan sekolah (Usman, 2013).

Jika ditinjau dari karakteristiknya remaja pada perkembangannya secara sosial, disebutkan bahwa remaja akan menjalin persahabatan dengan teman sebayanya atau peer group. Saat persahabatan ini dimulai remaja akan cenderung memilih teman yang cocok atau sesuai dengan kepribadiannya baik dari minat dan kesukaan terhadap sesuatu, sikap, nilai atau norma yang dianut dan kepribadian (Trevi \& Respati, 2012). Selain itu pada penelitian yang dilakukan oleh Widiharto et.al.(2012) mengenai bullying ditinjau dari harga diri dan pemahaman moral mendapatkan hasil bahwa ada hubungan yang signifikan antara harga diri dan pemahaman 
moral anak dengan bullying, dan menyarankan pada peneliti selanjutnya untuk menghubungkan bullying dengan faktor-faktor lain seperti empati dan sikap.

Dari beberapa uraian di atas maka konsep peneliti mengenai bullying yang dikaitkan dengan sikap siswa reguler terhadap siswa berkebutuhan khusus di kelas inklusi karena dari beberapa kasus yang telah diungkap bahwa tidak hanya siswa normal saja yang dapat menerima bullying dari teman-temannya melainkan siswa berkebutuhan khusus dapat menerimanya karena mereka tidak tahu ketika mendapat bullying. Menurut Thurstone (Walgito, 2003), sikap adalah suatu tingkatan afek yang menghasilkan sifat positif yaitu afek yang menyenangkan atau negatif, yaitu afek yang tidak menyenangkan dengan objek-objek psikologis. Menurut Walgito (Dayakisni\& Hudaniah, 2009), proses terbentuknya sikap mula-mula adalah dipengaruhi oleh faktor internal, yaitu secara fisiologis maupun psikologis. Selain itu juga faktor eksternal sehingga menghasilkan reaksi berupa sikap positif maupun negatif. Sehingga apa yang diperoleh oleh siswa reguler ketika berhubungan dengan siswa berkebutuhan khusus akan menghasilkan afek berupa reaksi positif atau negatif. Apabila sikap siswa reguler positif maka hasilnya adalah kecenderungan untuk bullying pada anak berkebutuhan khusus mejadi rendah sedangkan apabila sikap siswa reguler negatif maka kecenderungan untuk bullying pada anak berkebutuhan khusus akan tinggi.

Selain itu pada penelitian yang dilakukan oleh Salim (2013) mendapakan bahwa adanya hubungan positif antar perilaku bullying dengan empati siswa regular, yaitu semakin tinggi empati siswa reguler maka kecenderungan untuk melakukan bullying menjadi rendah terhadap siswa ASD. Sedangkan apabila empati siswa reguler tinggi maka kecenderungan melakukan defending tinggi pada anak ASD untuk menjadi korban bullying.

Berdasarkan penjelasan latar belakang tersebut di atas maka penelitian ini bertujuan untuk mengetahui hubungan sikap terhadap kecenderungan perilaku bullying yang dilakukan oleh siswa reguler terhadap siswa berkebutuhan khusus di kelas inklusi.

\section{Kecenderungan Bullying}

Kecenderungan adalah kesiapan seseorang dalam berperilaku, sedangkan bullying merupakan substansi dari perilaku agresif karena adanya ketidakseimbangan antara pelaku bullying dan korban bullying selain itu perilaku bullying terjadi berulang-ulang. Bullying memiliki tiga pihak yang terlibat dalam bullying ini, yaitu adanya the bullies (pelaku bullying), victims (korban bullying) dan bystander (saksi mata perilaku bullying). Bulles atau pelaku adalah mereka yang mengetahui cara menggunakan kekuatannya dengan melakukan bullying kepada korbannya yang lebih lemah dan tidak berdaya. Victims atau korban merupakan individu yang lebih lemah sehingga mendapatkan perlakuan berupa perilaku bullying. Sedangkan Bystander atau saksi mata merupakan orang yang menyaksikan tindakan bullying (Sullivan et.al., 2004; Swearer et.al.,2009).

Rigby (2002) dan Rigby et.al. (2004) menyebutkan bahwa bullying merupakan perilaku agresif atau menindas yang dilakukan karena ketidakseimbangan kekuatan, yang terjadi berlangulang, di sengaja dan diserang tanpa keadilan. Baik secara fisik, verbal maupun tidak langsung. Selain itu menurut Rigby (2002) terdapat empat aspek bentuk perilaku bullying, yaitu: pertama, bullying secara fisik seperti perilaku memukul, menendang dan perilaku menyakiti lainnya. Kedua, bullying verbal yaitu perilaku menyakiti yang dilakukan secara verbal seperti menghina, mengejek dan mengolok-olok. Ketiga, bullying yang dilakukan dengan mengguakan isyarat tubuh seperti mengancam. Keempat, bullying yang dilakukan dengan cara membentuk kelompok untuk menghasut agar menghidari atau menyakiti korban bullying. 
Karakteristik perilaku bullying pada seorang Bully yaitu adanya keinginan untuk menguasai atas diri seseorang, tidak mempedulikan keinginan orang lain atau korban karena yang paling penting adalah keinginannya dapat terpenuhi tidak mempedulikan sudut pandang orang lain atau keinginan dan harapan orang lain, serta kurang empati. Hal ini dinyatakan dalam perilakunya yang suka melakukan intimitasi, agresif, impulsive dan suka memukul. Hal ini di motivasi oleh rasa kebencian, perasaan iri terhadap orang lain atau korban dan adanya dendam yang harus dilampiaskan. Perilaku bullying ini juga bisa disebabkan karena adanya perasaan untuk menutupi kegelisahan dan perasaan malu sehingga dengan melakukan bullying rasa percaya diri akan muncul karena ada objek yang dibuatnysa tidak berarti (Rosada, 2010).

Karakteristik target korban bullying disebabkan faktor eksternal korban yang kecil dan lemah cenderung mendapat perilaku bullying dari temannya yang lebih besar. Bisa juga karena senioritas siswa terhadap adik kelasnya, berdasarkan pada penelitian Berntein dan Watson (1997). Faktor lain yang memungkinkan terjadinya bullying adalah latar belakang sosialekonomi dan budaya-agama, status sebagai siswa baru, karena warna kulit dan rambut dan faktor intelektual (Wiyani, 2012).

\section{Sikap Siswa Reguler terhadap Siswa Berkebutuhan Khusus}

Menurut Mann (Azwar, 2013), sikap memiliki beberapa komponen penting yang saling mempengaruhi yaitu kognitif, afektif, dan konatif. Komponen kognitif yang merupakan dasar pengetahuan dari informasi yang didapatkan sehingga terbentuk suatu keyakinan atau kepercayaan mengenai apa yang dilihat dan diketahui dari objek sikap sehingga menciptakan suatu gagasan bagi objek. Selanjutnya komponen afektif berkaitan dengan perasaan senang dan tidak senang yang melibatkan aspek secara emosional. Sementara itu komponen konatif adalah kesiapan untuk berhubungan dengan orang lain yaitu menunjuk pada perilaku atau kecenderungan seseorang untuk berperilaku yang berasal dari diri seseorang yang kaitannya dengan objek. Artinya bagaimanapun perilaku seseorang itu karena di tentukan oleh hasil kepercayaan kognitif nya dan perasaannya terhadap objek.

Dayakisni dan Hudaniah (2009) serta Tresvi \& Respati (2012) mengungkapkan bahwa sikap adalah pandangan atau kesiapan seseorang dalam bertingkahlaku, baik dalam bentuk sikap positif maupun sikap negatif. Ketika seseorang menyikapi suatu objek secara positif maka kecenderungan perilaku yang muncul adalah mendekati, menyenangi, dan memunculkan harapan terhadap objek tertentu. Sedangkan perilaku yang dimunculkan ketika bersikap negatif adalah kecenderungan untuk berperilaku menjauhi, menghindari, membenci objek tertentu sampai ada kecenderungan untuk melakukan bullying.

Kecenderungan perilaku seseorang secara konsisten, sejalan dengan proses kognisi dan afeksi sehingga membentuk sikap secara individual. Oleh karena itu sikap seseorang yaitu siswa reguler akan digambarkan dalam bentuk perilaku terhadap objek yang dihadapinya yaitu siswa berkebutuhan khusus. Azwar (2013) menjelaskan ada beberapa faktor yang mempengaruhi terbentuknya sikap: pertama, pengalaman hidup yang terbentuk secara emosional. Kedua, kebudayaan yang melekat mengikuti perkembangan hidup seseorang. Ketiga, konformis terhadap orang yang dianggap penting. Keempat, media massa yang memiliki pesan-pesan sugestif. Kelima, Agama dengan fungsi dasar penetap konsep moral. Dan keenam, faktor emosional sebagai pertahanan ego.

Suran dan Rizzo (1979) (Mangunsong, 2014) mendefinikan ABK adalah anak yang memiliki perbedaan dalam beberapa dimensi kemanusiaan, yaitu secara fisik, inteligensi, maupun sosial-emosional yang tidak berfungsi, sehingga menghambat fungsi kemanusiaannya. Seperti, tuli, buta, gangguan bicara, cacat secara fisik, retardasi mental, dan gangguan secara emosional. Selain itu anak-anak CIBI (cerdas istimewa dan bakat istimewa) dikategorikan 
sebagai anak khusus karena memerlukan penanganan dari tenaga ahli atau professional. Hallahan dan Kauffman (2009) menjelaskan ABK dari sudut pendidikan adalah mereka yang berbeda dengan siswa pada umumnya. Hambatan yang disandang ABK bermacam-macam baik secara mental, gangguan belajar karena susah mengfokuskan dalam satu hal, gangguan secara sosial maupun emosional, keterbatasan dalam berkomunikasi, fisik, pendengaran, penglihatan, autism maupun CIBI (cerdas istimewa dan bakat istimewa). Karena perbedaan ini maka kebutuhan pendidikan dan penyampaian pendidikan harus secara khusus, dengan mempertimbangkan beberapa hal seperti karakter kebutuhan dari masing-masing siswa ABK.

\section{Hubungan antara Sikap Siswa Reguler terhadap ABK dan Kecenderungan Bullying}

Sikap yang munculkan dari siswa reguler terhadap siswa berkebutuhan khusus adalah apa yang dilihat dan apa yang dirasakan oleh siswa reguler terhadap keterbatasan siswa berkebutuhan khusus baik secara fisik, sosial-emosional dan inteligensinya. Dalam hal ini siswa reguler bisa menunjukkan sikap berupa sikap positif maupun berupa sikap negatif. Sikap positif yang ada pada siswa reguler adalah siswa reguler akan cenderung menerima kehadiran siswa berkebutuhan khusus dengan beberapa kekurangannya baik secara fisik, sosial-emosional dan inteligensinya, sehingga ketika siswa berkebutuhan khusus mengalami kesulitan siswa reguler akan senantiasa bersedia menolong dan peduli terhadap kekurangan siswa berkebutuhan khusus, sebaliknya apabila sikap yang ada pada siswa reguler negatif terhadap siswa berkebutuhan khusus maka siswa reguler akan melakukan penolakan dan tidak bisa menerima siswa berkebutuhan khusus dengan kekurangannya secara fisik, sosial-emosional dan inteligensinya sehingga yang dilakukan adalah menghindari dan penolakan di lingkungan pergaulannya sehingga memungkinkan siswa berkebutuhan khusus mendapat bullying baik bullying secara fisik, verbal, isyarat tubuh dan berkelompok.

Bullying sendiri sering terjadi pada siswa yang terlihat lemah dan tidak dapat melindungi diri, sehingga dampak yang didapat dari korbannya sangat membekas baik secara fisik maupun psikologis. Bullying tidak hanya melibatkan korban dan pelaku bullying saja melainkan juga adanya bystanders atau saksi mata. Meskipun seperti itu bystanders tidak bisa melakukan apaapa dalam menghentikan bullying dan cenderung menghindar (Sullivan et.al., 2004).

Penelitian masalah bullying sudah banyak dilakukan pada remaja dengan perkembangan normal di sekolah umum, namun penelitian mengenai bullying di kelas inklusi masih sedikit. Menurut Roekel et.al (Salim, 2013), ada dua alasan remaja ABK memiliki resiko tinggi pada keterlibatannya dalam bullying, yaitu: pertama, karena ketidakmampuannya dalam berinteraksi secara sosial. Dan kedua, yaitu karena ABK sedikit memiliki teman

Adapun kerangka berpikir penelitian adalah sebagai berikut:

\section{Gambar 1}

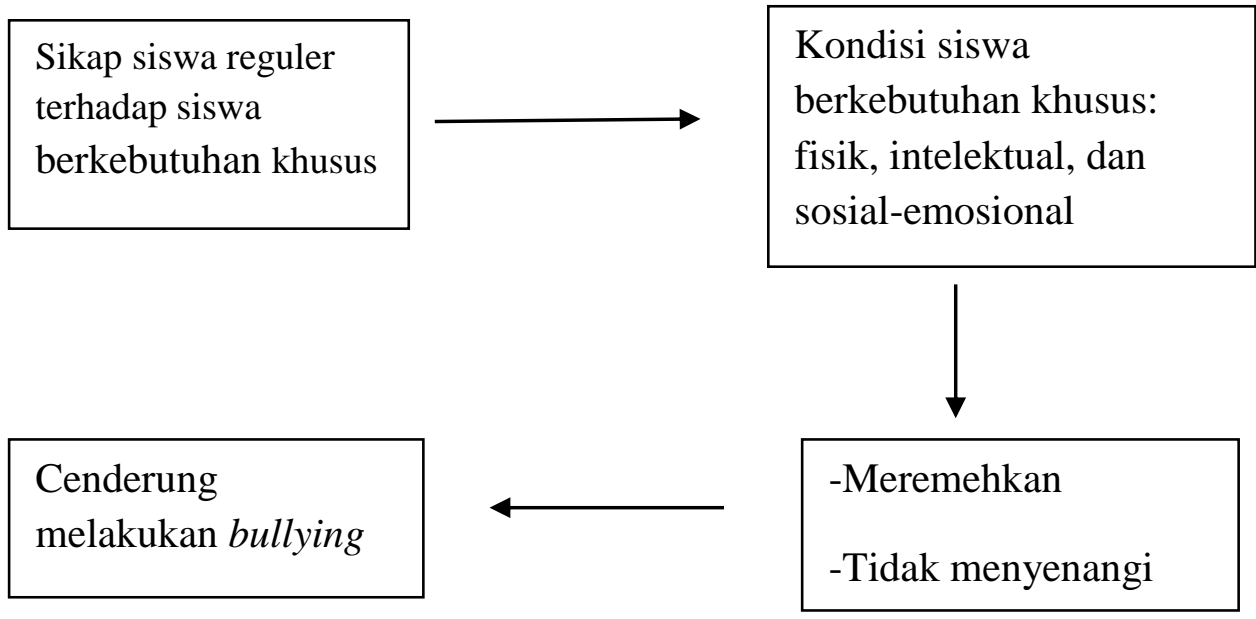


Dari kerangka berpikir diatas menurut peneliti, penelitian ini penting dilakukan karena belum ada penelitian yang melakukan penelitian serupa terutama di Indonesia. Sehingga peniliti tertarik untuk meneliti kecenderungan perilaku bullying ditinjau dari sikap siswa reguler terhadap siswa berkebutuhan khusus di kelas inklusi.

\section{Hipotesis}

Hipotesis dari penelitian ini adalah ada hubungan negatif antara sikap siswa reguler terhadap siswa berkebutuhan khusus dan kecenderungan bullying di kelas inklusi. Siswa reguler dengan sikap lebih positif maka kecenderungan untuk bullying pada siswa berkebutuhan khusus menjadi rendah, sedangkan siswa reguler dengan sikap lebih negatif maka kecenderungan untuk bullying pada anak berkebutuhan khusus lebih tinggi.

\section{METODE PENELITIAN}

\section{Rancangan Penelitian}

Penelitian ini menggunakan pendekatan non-eksperimental yaitu pendekatan kuantitatif korelasional antara dua variabel. Hal ini dimaksudkan adalah untuk mengetahui ada atau tidak adanya hubungan antara dua variabel, yaitu variabel $\mathrm{X}$ dan variabel $\mathrm{Y}$.

\section{Subjek Penelitian}

Adapun teknik pengambilan sampel penelitian adalah teknik sampling non-probabilitas yaitu berupa teknik purposives sampling. Yang dimaksud dalam dalam teknik ini adalah teknik pengambilan sampel dengan mempertimbangkan kriteria-kriteria tertentu (dalam Prasetyo \& Jannah, 2012). Kriteria yang dimaksud dalam hal ini adalah dengan memperhatikan beberapa pertimbangan, misalnya alasan keterbatasan waktu, tenaga dan dana sehingga sampel yang diambil tidak terlalu besar dan terlalu jauh (Azwar, 2014).

Target subjek penelitian yang digunakan adalah siswa reguler yang berada pada tingkat SMP di kelas inklusi. Sesuai dengan topik penelitian yaitu siswa reguler baik perempuan maupun laki-laki dengan tingkatan pendidikan SMP di kelas inklusi. Populasi dalam penelitian ini adalah bersifat homogen karena berada pada usia yang sama yaitu antara 13-16 tahun dan pada sekolah inklusi, sebanyak 200 subjek.

\section{Variabel dan Instrumen Penelitian}

Agar tidak menimbulkan pembiasan saat memahami permasalahan, maka peneliti membuat definisi operasinal sebagai berikut: terdapat dua variabel yang digunakan dalam penelitian ini, yaitu kecenderungan bullying sebagai variabel terikat dan sikap siswa reguler sebagai variabel bebas. Kecenderungan bullying adalah perilaku agresif yang dilakukan oleh siswa reguler baik laki-laki atau perempuan yang berada di kelas inklusi dan dilakukan secara terencana dan berulang-ulang dengan tujuan menjadikan siswa berkebutuhan khusus merasa tidak nyaman. Sikap adalah pandangan siswa reguler baik laki-laki maupun perempuan dalam memutuskan suatu perilaku baik menolong, menerima, menghargai, mendekati dan menyenangi atau siswa reguler berlaku membenci, mengucilkan dan meremehkan kepada siswa berkebutuhan khusus hal ini dilakukan secara verbal maupun non-verbal, yang melibatkan komponen sikap yaitu kognitif, afektif dan konatif.

Skala yang digunakan untuk mengukur kecenderungan bullying menggunakan skala yang disusun oleh peneliti. Skala yang disusun bersadarkan pada aspek menurut Rigby (2002), yaitu:

a. Bullying secara fisik

b. Bullying secara verbal 
Sikap Siswa Reguler Terhadap Siswa .... Uswatun, Ni'matuzahroh, Yuni

c. Bullying dengan isyarat tubuh

d. Bullying dengan cara membentuk kelompok

Metode yang digunakan dalam pengumpulan data untuk mengukur sikap terhadap siswa berkebutuhan khusus menggunakan skala sikap siswa reguler terhadap siswa berkebutuhan khusus yang mengungkap 3 aspek yaitu (1) kognitif yaitu kepercayaan atau keyakinan mengenai apa yang berlaku bagi objek yang disikapi ,(2) afektif yaitu mengaitkan emosional subjektif dalam menyikapi suatu objek, dan (3) konatif yaitu hasil berupa perilaku atau hanya kecenderungan berperilaku yang berkaitan dengan asumsi pada kepercayaan dan perasaan secara emosional. Skala sikap siswa reguler terhadap siswa berkebutuhan khusus ini juga harus dilakukan try out untuk mengetahui validitas item dalam skala.

\section{Validitas Instrumen}

Berdasarkan proses validitas item alat ukur padatry out yang dilakukan yaitu dengan menyebarkan skala kepada 65 responden diperoleh hasil validitas dari setiap item sebagai berikut:

Tabel 1. Indeks Validitas Alat Ukur

\begin{tabular}{lccc}
\multicolumn{1}{c}{ Alat Ukur } & $\begin{array}{c}\text { Jumlah Item } \\
\text { Diujikan }\end{array}$ & $\begin{array}{c}\text { Jumlah Item } \\
\text { Valid }\end{array}$ & Indeks Validitas \\
\hline $\begin{array}{l}\text { Skala Sikap Siswa Reguler } \\
\text { Terhadap Siswa Berkebutuhan }\end{array}$ & 44 & 15 & $0.330-0.589$ \\
Khusus & & & \\
Skala Kecenderungan Bullying & 31 & 20 & $0.323-0.549$ \\
\hline
\end{tabular}

Berdasarkan tabel 1. diperoleh hasil dari 44 item pada skala sikap siswa reguler terhadap siswa berkebutuhan khusus yang telah di ujikan, diperoleh sebesar 15 item yang valid setelah diujikan melalui uji statistik menggunakan program SPSS versi 17.00. indeks validitas dari skala sikap siswa reguler terhadap siswa berkebutuhan khusus yang diujikan diperoleh validitas item terendah adalah 0.330 dan validitas item tertinggi adalah 0.589. Selain itu, pada skala kecenderungan perilaku bullying dari 31 item yang telah diujikan, diperoleh 20 item yang valid. Indeks validitas dari skala kecenderungan perilaku bullying diperoleh validitas item terendah adalah 0.323 dan validitas iten yang tertinggi adalah 0.549 .

\section{Reliabilitas Instrumen}

Tabel 2. Indeks Reliabilitas Alat Ukur

\begin{tabular}{lc}
\hline \multicolumn{1}{c}{ Alat Ukur } & Alpha \\
\hline Skala Sikap Siswa Reguler Terhadap Siswa Berkebutuhan Khusus & 0.728 \\
Skala Kecenderungan Bullying & 0.822 \\
\hline
\end{tabular}

Berdasarkan tabel 2. dapat disimpulkan bahwa kedua instrumen ini reliabel digunakan dalam penelitian, hal ini jika dibandingkan dengan syarat crobanch alpha yaitu minimal 0,6 atau 
60\% (Priyatno, 2011). Hal ini dapat disimpulkan bahwa kedua instrumen yang digunakan dalam penelitian ini memiliki tingkat validitas dan reliabilitas yang memadai.

\section{Prosedur dan Analisis Data Penelitian}

Prosedur dalam penelitian yang pertama adalah tahap persiapan yaitu tahap persiapan skala likert. Untuk skala kecenderungan perilaku bullying peneliti membuat sendiri disesuaikan dengan apa yang ingin diungkap berdasarkan pada teori Rigby (2002), begitu juga skala sikap siswa reguler terhadap siswa berkebutuhan khusus dibuat berdasarkan aspek yang ada dalam sikap menurut Mann (Azwar, 2013). Tahap kedua, mencari lokasi penelitian yang relevan yaitu sekolah yang memiliki program inklusi dan subyek target penelitian adalah siswa inklusi di tingkat SMP yaitu SMPN 18 Malang, SMP Muhammadiyah 2 Malang dan SMP Satu Atap Merjosari Malang. Tahap ketiga adalah try out penyebaran skala kecenderungan bullying dengan item sebanyak 31 dan pengisian skala sikap siswa reguler terhadap siswa berkebutuhan khusus dengan 44 item yang dilakukan di SMPN 18 Malang sebanyak 65 responden setelah itu dihitung validitas dan reliabilitasnya.

Tahap keempat pelaksanaan penelitian, di mana setelah diketahui kedua alat ukur yang telah di uji reliabilitas dan validitasnya dibagikan kepada subjek penelitian sesuai dengan karakteristik yang telah ditentukan. Tahap kelima, metode analisis yang digunakan dalam penelitian adalah untuk mengukur hubungan dengan data berupa data interval. Karena yang dimaksudkan adalah untuk mengetahui ada atau tidak adanya hubungan antara variabel $\mathrm{X}$ dengan variabel $\mathrm{Y}$, sehingga pengelolahan data yang digunakan adalah korelasi product-moment dibantu dengan program SPSS for windows.

\section{HASIL PENELITIAN}

Hasil data penelitian yang diperoleh dari 200 subjek penelitian atau siswa reguler, peneliti dapat menentukan skor tinggi, sedang dan rendah pada variabel sikap siswa reguler terhadap siswa berkebutuhan khusus dan variabel kecenderungan bullying yang di tunjukkan pada tabel berikut:

Tabel 3. Perhitungan $t$-score sikap siswa reguler terhadap siswa berkebutuhan khusus

\begin{tabular}{ccccc}
\hline $\begin{array}{l}\text { Sikap siswa reguler } \\
\text { terhadap siswa } \\
\text { berkebutuhan khusus }\end{array}$ & Kategori & Interval & Frekuensi & Persentase \\
\hline Sikap Positif & Tinggi & $\mathrm{T}>50$ & 115 & \\
Sikap Negatif & Rendah & $\mathrm{T}<50$ & 85 & $57.5 \%$ \\
\hline Total & & & $\mathbf{2 0 0}$ & $\mathbf{1 0 0 \%}$ \\
\hline
\end{tabular}

Berdasarkan pada tabel 3. diatas diketahui bahwa dari 200 siswa diperoleh sebanyak 115 subjek (57.5\%) memiliki tingkat sikap terhadap siswa berkebutuhan khusus yang tinggi, sedangkan 85 subjek (42.5\%) memiliki sikap terhadap siswa berkebutuhan khusus yang rendah. Dalam hal ini menunjukkan bahwa secara deskriptif bahwa sebagian besar siswa reguler memiliki sikap positif terhadap siswa berkebutuhan khusus yang tinggi 
Sikap Siswa Reguler Terhadap Siswa .... Uswatun, Ni'matuzahroh, Yuni

Tabel 4. Perhitungan $t$-score kecenderungan bullying

\begin{tabular}{cccc}
\hline $\begin{array}{c}\text { Kategori kecenderungan } \\
\text { bullying }\end{array}$ & Interval & Frekuensi & Persentase \\
\hline Tinggi & $\mathrm{T}>50$ & 106 & \\
Rendah & $\mathrm{T}<50$ & 94 & $47 \%$ \\
\hline Total & & $\mathbf{2 0 0}$ & $\mathbf{1 0 0 \%}$ \\
\hline
\end{tabular}

Berdasarkan pada tabel 4.diketahui bahwa kecenderungan bullying pada 200 subjek penelitian, diperoleh sebanyak 106 subjek (53\%) memiliki tingkat kecenderungan bullying yang tinggi, sedangkan 94 subjek (47\%) memiliki kecenderungan bullying yang rendah. Sehingga secara deskriptif sebagian besar siswa reguler memiliki kecenderungan perilaku bullying yang tinggi.

Hasil penelitian pada perhitungan korelasi yang telah dilakukan dengan perhitungan SPSS versi 17.00 diperoleh seperti pada tabel berikut:

\section{Tabel 5. Korelasi Sikap Siswa Reguler terhadap Siswa Berkebutuhan Khusus dengan Kecenderungan Bullying}

\begin{tabular}{ll}
\hline Koefisien korelasi $(\mathbf{r})$ & Indeks Analisis \\
\hline Koefisien korelasi $(\mathrm{r})$ & -0.234 \\
Koefisien determinasi $\left(\mathrm{r}^{2}\right)$ & 0.054 \\
Taraf Kemungkinan Kesalahan & $1 \%(0.01)$ \\
$P$ (nilai signifikansi) & 0.000 \\
\hline
\end{tabular}

Dari penjelasan tabel 5.diatas maka dapat disimpulkan bahwa ada hubungan yang negatif antara sikap siswa reguler terhadap siswa berkebutuhan dengan kecenderungan bullying. Hasil pada tingkat signifikansi yaitu ditunjukkan 0.000 dari taraf signifikansi yang digunakan yaitu $0.01(0.000<0.01)$ sehingga dapat dikatakan bahwa ada hubungan antara sikap siswa reguler terhadap siswa berkebutuhan khusus dengan kecenderungan bullying. Semakin positif sikap siswa reguler terhadap siswa berkebutuhan khusus maka semakin rendah kecenderungan bullying. Hal ini ditunjukkan dengan koefisien korelasi (r) bernilai negatif sebesar -0.234.

Koefisien determinasi $\left(\mathrm{r}^{2}\right)$ variabel sikap siswa reguler terhadap siswa berkebutuhan husus berdasarkan hasil analisis data diatas adalah 0.054 yang berarti sumbangan efektif dari sikap siswa reguler terhadap siswa berkebutuhan khusus yang diberikan dalam kecenderungan bullying sebesar 5.4\% sedangkan sisanya sebesar 94.6\% pengaruh faktor lain atau variabel lain. Faktor-faktor yang mempengaruhi bullying ini seperti yang dijelaskan oleh Anderson dan Bushman (2002) yang membedakan faktor bullying menjadi 2 yaitu faktor personal meliputi kepribadian, emosi dan genetik. Faktor situasional meliputi iklim sekolah, perkembangan teknologi dan nilai dalam suatu kelompok.

\section{DISKUSI}

Penelitian yang telah dilakuka bertujuan untuk mengetahui hubungan antara sikap siswa reguler terhadap siswa berkebutuhan khusus dan kecenderungan bullying. Hasil analisis 
menunjukkan hipotesis yang berbunyi "Adanya hubungan negatif antara sikap siswa reguler terhadap siswa berkebutuhan khusus dengan kecenderungan bullying di kelas inklusi" dapat diterima dengan taraf signifikasi sebesar $1 \%$

Sikap dalam pandangan Dayakisni dan Hudaniah (2009) serta Tresvi dan Respati (2012) adalah pandangan atau kesiapan seseorang dalam bertingkahlaku, baik dalam bentuk positif maupun negatif. Ketika seseorang menyikapi suatu objek secara positif maka kecenderungan perilaku yang muncul adalah mendekati, menyenangi, dan memunculkan harapan terhadap objek tertentu. Sedangkan perilaku yang dimunculkan ketika bersikap negatif adalah kecenderungan untuk berperilaku menjauhi, menghindari, membenci objek tertentu sampai ada kecenderungan untuk melakukan bullying. Sikap yang dimaksudkan dalam penelitian ini adalah sikap siswa reguler terhadap siswa berkebutuhan khusus mengenai kondisi secara fisik siswa berkebutuhan khusus, intelektual dan kondisi sosial-emosional siswa berkebutuhan khusus.

Sikap yang munculkan dari siswa reguler terhadap siswa berkebutuhan khusus adalah apa yang dilihat dan apa yang dirasakan oleh siswa reguler terhadap keterbatasan siswa berkebutuhan khusus baik secara fisik, sosial-emosional dan inteligensinya. Dalam hal ini siswa reguler bisa menunjukkan sikap berupa sikap positif maupun berupa sikap negatif. Sikap positif yang ada pada siswa reguler adalah siswa reguler akan cenderung menerima kehadiran siswa berkebutuhan khusus dengan beberapa kekurangannya baik secara fisik, sosial-emosional dan inteligensinya, sehingga ketika siswa berkebutuhan khusus mengalami kesulitan siswa reguler akan senantiasa bersedia menolong dan peduli terhadap kekurangan siswa berkebutuhan khusus, sebaliknya apabila sikap yang ada pada siswa reguler negatif terhadap siswa berkebutuhan khusus maka siswa reguler akan melakukan penolakan dan tidak bisa menerima siswa berkebutuhan khusus dengan kekurangannya secara fisik, sosial-emosional dan inteligensinya sehingga yang dilakukan adalah menghindari dan penolakan di lingkungan pergaulannya sehingga memungkinkan siswa berkebutuhan khusus mendapat bullying baik bullying secara fisik, verbal, isyarat tubuh dan berkelompok.

Dari hasil analisis data diperoleh koefisien korelasi (r) sebesar -0,234 dengan taraf signifikasi (p) sebesar $0.000<0.01$. Hal ini menunjukkan bahwa ada hubungan dengan arah korelasi negatif yang signifikan antara variabel sikap siswa reguler terhadap siswa berkebutuhan khusus dengan variabel kecenderungan bullying. Nilai koefisien korelasi $(r)=-0,234$ menunjukkan adanya hubungan negatif antara dua variabel yang diteliti. Hal ini berarti apabila sikap siswa reguler terhadap siswa berkebutuhan khusus lebih positif maka kecenderungan perilaku bullying menjadi rendah. Sebaliknya, apabila sikap siswa reguler terhadap siswa berkebutuhan khusus negatif maka kecenderungan perilaku bullying menjadi tinggi. Hasil tersebut selaras dengan penelitian sebelumnya yang membuktikan bahwa ada hubungan yang negatif antara sikap dengan perilaku agresif, seperti pada penelitian Faiqoh dan Falah (tt.) yang meneliti tentang hubungan antara sikap terhadap pasien penyakit jiwa dengan perilaku agresif perawat pasien penyakit jiwa, hasil dari penelitian tersebut menunjukkan bahwa ada hubungan negatif yang signifikan antara sikap perawat terhadap pasien penyakit jiwa dengan perilaku agresif perawat pasien penyakit jiwa.

Subjek pada penelitian ini adalah siswa reguler pada sekolah inklusi di tingkat SMP, di mana siswa reguler akan berinteraksi dengan siswa berkebutuhan khusus di sekolah. Kondisi siswa berkebutuhan khusus yang berbeda dengan siswa reguler baik secara fisik, sosioemosional maupun inteligensi akan menjadikan atau menuntut siswa reguler harus bisa menerima kondisi apapun yang ada pada siswa berkebutuhan khusus. Ketika siswa reguler dapat bersikap positif terhadap siswa berkebutuhan khusus maka siswa reguler akan cenderung menerima dan peduli dengan keadaan apapun yang sedang disandang oleh siswa berkebutuhan khusus, sebaliknya apabila siswa reguler memiliki sikap yang negatif terhadap siswa 
berkebutuhan khusus maka siswa reguler akan meremehkan, membenci, hingga memunculkan kecenderungan untuk berperilaku bullying kepada siswa berkebutuhan khusus. Hal ini sejalan dengan penelitian yang dilakukan oleh Tumon (2014) yang menemukan bahwa pelaku tindakan bullying cenderung mencari korban dengan kriteria adalah teman yang kurang bisa dalam bergaul,teman dengan kekurang fisik dan mereka yang menjadi adik kelas para pelaku bullying.

Bullying merupakan substansi dari perilaku agresif karena adanya ketidakseimbangan antara pelaku bullying dan korban bullying selain itu perilaku bullying terjadi berulang-ulang, bullying juga merupakan perilaku agresi yang dilakukan secara terencana dengan memanfaatkan ketidak berdayaan korbannya. Rigby (2002) menyebutkan bahwa terdapat empat aspek bentuk perilaku bullying, yaitu: pertama, bullying secara fisik seperti perilaku memukul, menendang dan perilaku menyakiti lainnya. Kedua, bullying verbal yaitu perilaku menyakiti yang dilakukan secara verbal seperti menghina, mengejek dan mengolok-olok. Ketiga, bullying yang dilakukan dengan mengguakan isyarat tubuh seperti mengancam. Dan keempat, bullying yang dilakukan dengan cara membentuk kelompok untuk menghasut agar menghidari atau menyakiti korban bullying.

Dalam penelitian ini juga sesuai dengan teori yang disebutkan oleh Nashori (Faiqoh \& Falah, tt) bahwa faktor yang mempengaruhi perilaku agresif adalah sikap terhadap sumber agresi yaitu siswa berkebutuhan khusus yang merupakan objek dari terbentuknya sikap. Kondisi siswa berkebutuhan khusus yang berbeda dengan siswa reguler menjadikan siswa reguler dituntut untuk dapat menerima kondisi temannya dan membantu memenuhi kebutuhan temannya yang berkebutuhan khusus. Jika ditilik kembali pada subjek penelitian pada tingkat SMP yang berkisar pada umur 13-16 tahun merupakan masa pubertas yaitu masa pencarian jati diri dan masa untuk mendapatkan teman yang sesuai dengan

Dalam penelitian ini diketahui bahwa sumbangan efektif dari variabel sikap siswa reguler terhadap siswa berkebutuhan khusus dengan kecenderungan bullying adalah sebesar 5.4\% sedangkan sisanya $94.6 \%$ dipengaruhi oleh faktor lain atau variabel lain yang tidak diteliti. Swearer et.al. (2009) mengungkapkan ada beberapa faktor lain yang mempengaruhi perilaku bullying yaitu adanya faktor dari diri sendiri yaitu mengenai stabilitas emosi individu, pola pengasuhan atau hubungan keluarga yang kaku secara emosional, bullying yang dilakukan untuk mendapatkan pengakuan dari teman sebayanya, iklim sekolah yang dibangun secara negatif, dan hubungan masyarakat yang mengitimidasi. Jika dirangkum maka faktor-faktor tersebutdapat terbagi menjadi dua faktor, yaitu faktor internal dan faktor eksternal. Pada faktor internal berhubungan dengan faktor psikologis mengenai gangguan psikologis maupun gangguan secara emosional, sedangkan pada faktor eksternal dipengaruhi oleh lingkungan yaitu teman sebaya, keluarga yang kurang harmonis, ekonimi keluarga dan penggunaan teknologi yang tidak bijaksana. Sikap merupakan faktor kecil yang mempengaruhi perilaku bullying sedangkan sebagian besar lain dipengaruhi oleh faktor-faktor ekstenal lain.

Hasil temuan dari penelitian ini menggambarkan bahwa dari 200 subjek penelitian atau siswa, diperoleh sebesar 115 subjek (57.5\%) memiliki sikap yang positif terhadap siswa berkebutuhan khusus, dan sebesar 85 subjek yaitu (42.5\%) siswa reguler memiliki sikap yang negatif terhadap siswa berkebutuhan khusus. Dengan demikian, dapat dideskripsikan bahwa sebagian besar siswa siswa reguler memiliki sikap yang lebih positif terhadap siswa berkebutuhan khusus. Hal ini seperti yang telah dijelaskan di awal-awal bahwa sikap siswa reguler terhadap siswa berkebutuhan khusus adalah pandangan siswa reguler baik laki-laki maupun perempuan dalam memutuskan suatu perilaku baik menolong, menerima, menghargai, mendekati dan menyenangi atau siswa reguler berlaku menghindari, menjauhi, membenci, mengucilkan dan meremehkan kepada siswa berkebutuhan khusus hal ini dilakukan secara verbal maupun non-verbal, yang melibatkan komponen sikap yaitu kognitif, afektif dan konatif. 
Selain itu pada variabel kecenderungan perilaku bullying pada hasil penelitian menemukan, bahwa dari 200 subjek penelitian atau siswa yang diteliti, menggambarkan bahwa 106 subjek (53\%) termasuk dalam kategori kecenderungan bullying yang tinggi dan sebanyak 94 subjek (47\%) termasuk dalam kategori kecenderungan bullying yang rendah.Pada analisis data dan pembahasan dalam penelitian ini didapatkan bahwa penelitian cukup memberikan gambaran bahwa variabel yang diteliti memiliki hubungan yang negatif yaitu antara sikap siswa reguler terhadap siswa berkebutuhan khusus dengan kecendrungan bullying.

\section{SIMPULAN DAN IMPLIKASI}

Hasil penelitian yang dilakukan pada siswa reguler di sekolah inklusi tingkat SMP menunjukkan bahwa hipotesis diterima karena terdapat hubungan negatif yang signifikan antara sikap siswa reguler terhadap siswa berkebutuhan khusus dengan kecenderungan bullying.Dengan nilai koefisien korelasi sebesar -0.234 dan nilai signifikansi $0.000(\mathrm{p}<0.01)$.

Sumbangan efektif variabel sikap siswa reguler terhadap siswa berkebutuhan khusus dengan kecenderungan bullying diperoleh nilai sebesar 5.4\% dan untuk sisanya sebesar $94.6 \%$ dipengaruhi oleh variabel atau faktor lain yang tidak diteliti.

Implikasi dari penelitian ini adalah diharapkan guru dapat memberikan informasi tentang keadaan siswa berkebutuhan khusus dan memberikan sosialisasi tentang cara bersikap maupun berperilaku yang sesuai dengan nilai ataupun norma yang berlaku tanpa membedakan siswa reguler maupun siswa berkebutuhan khusus. Pada sikap positif yang ditunjukkan oleh siswa reguler terhadap siswa berkebutuhan khusus, guru dapat memberikan ganjaran atau reward yang positif sehingga dapat memperkuat sikap positif dan menghindari perilaku bullying. Karena dengan sikap positif terhadap siswa berkebutuhan khusus maka akan menciptakan kepedulian dan keharmonisan antara siswa reguler dengan siswa berkebutuhan khusus. Selanjutnya pada peneliti yang akan melakukan penelitian serupa disarankan untuk memperhatikan kemungkinan adanya faktor-faktor lain yang mempengaruhi perilaku bullying seperti faktor kepribadian, emosi, iklim sekolah, dan perkembangan teknologi.

Kepada peneliti selanjutnya diharapkan untuk menghubungkan dengan variabel lain atau melakukan penelitian dengan model penelitian eksperimen sehingga peneliti dapat menjadi partisipan langsung dalam mengikuti semua kegiatan yang dilakukan oleh siswa berkebutuhan khusus dengan siswa reguler. Selanjutnya, data yang peroleh akan lebih maksimal dan akan baik dengan memperhatikan kondisi siswa berkebutuhan khusus dengan siswa reguler dikelas inklusi.

\section{DAFTAR PUSTAKA}

Anderson, C.A., \& Dewall, C.N. (2011). The general aggression model: theoretical extensions to violence. Psychology of violence American Psychological Association, 1.

Anderson, C.A \& Bushman, B.J. (2002).Human Aggression. Annual Reviews Psychology.

Azwar, S. (2014).Metode penelitian. Yogyakarta. Pustaka Pelajar.

Azwar, S. (2013).Sikap Manusia: Teori dan pengukuran. Yogyakarta: Pustaka Pelajar.

Bernstein, J.Y. \& Watson, M.W. (1997). Children who are targets of bullying: a victim pattern. Journal Of Interpersonal Violence.

Borowsky, I.W.,et.al. (2013). Suicidal thinking and behavior among youth involved in verbal and social bullying: risk and protective factors. Journal Of Adolescent Health.

Dayakisni, T.\&Hudaniah. (2009). Psikologi Sosial. Malang: UMM Press.

Durand, V.,et.al. (2013). Bullying and substance use in children and adolescents.Journal Addiction Research \& Therapy. 
Sikap Siswa Reguler Terhadap Siswa .... Uswatun, Ni'matuzahroh, Yuni

Faiqoh E. \& Falah F. (tt). Hubungan antara sikap terhadap pasien penyakit jiwa dengan perilaku agresif perawat pasien penyakit jiwa. Jurnal Proyeksi, 6, 89-99.

Hallahan, D.P., Kauffman, J.M.\& Pullen P.G. (2009). Exceptional Children: an Introduction to Special Education (11 $1^{\text {th }}$ ed.). Allyn \& Bacon: Boston.

Mangunsong, F. (2014).Psikologi dan Pendidikan Anak Berkebutuhan Khusus: Jilid I Edisi 2014. UI Depok. LPSP3 UI

Muslim, A.A. (2012). Perbedaan kecenderungan Perilaku bullying ditinjau dari tipe kepribadian ekstrovert dan introvert pada remaja. Universitas Muhammadiyah Malang. Malang.

Pellegrini, A. D., \& Bartini, M. (2000).An empirical comparison of methods of sampling aggression and victimization in school settings.Journal Of Educational Psychology.

Prasetyo, B \& Jannah, L.M. (2012).Metode penelitian kuantitatif. Jakarta: Rajawali Pers.

Priyatno, D. (2011). Buku saku analisis statistika data SPSS.Jakarta: PT. Buku Seru

Rigby, K (2002).New Prespective on bullying. London: Jessica Kingsley.

Rigby, K., Smith, P.K.,\& Pepler, D. (2004).Bullying in schools: How successful can intervention be?.Cambidge.Cambridge University Press.

Rosada, A. (2010). I am not a bully, I am a buddy: sebuah program penanganan bullying di SD tumbuh 2 yogyakarta. Disertasi doctoral, Program Magister Profesi Psikologi, Universitas Gadjah Mada, Yogyakarta.

Ruggieri, S.,et.al. (2013). Selection and influence effects in defending a victim of bullying: the moderating effects of school context. ProcediaSocial And Behavioral Sciences, 79, 117 126.

Salim, M. (2013).Hubungan antara empati dengan perilaku bullying dan dafending terhadap siswa dengan asd; studi pada siswa reguler di smpn inklusif di jakarta.Universitas Indonesia. Depok

Sullivan, K.Cleary, M. \& Sullvan, G.(2004).Bullying Secondary Schools: What it looks like and How to Manage it.California: Corwin pres

Swearer, S.M., Espelage, D.L \&Napolitano, S.A (2009).Bullying prevention and intervention: realistic strategies for scools. New York: The Guliford Press

Trevi,\& Respati W. S. (2012). Sikap siswa kelas X SMK Y tangerang terhadap bullying.Jurnal Psikologi,. 10.

Tumon, M. (2014), Studi deskriptif perilaku bullying pada remaja.Jurnal ilmiah mahasiswa universitas Surabaya. 3,1.

Unknown. (2014). Memilih sekolah yang benar untuk anak autis.(Online). Diakses tanggal 7 maret 2015 diperoleh dari http://segiempat.com/sehat/psikologi/memilih-sekolah-yang-benaruntuk-anak-autis/

Unknown. (2015). Sekolah inklusi di Indonesia masih sangat terbatas.(Online). Diakses tanggal 7 maret 2015 diperoleh dari

http://www.suara.com/lifestyle/2014/12/09/200538/sekolah-inklusi-di-indonesia-masihsangat-terbatas

Unknown. (2014). Begini kronologi kasus kejahatan seksual murid TK JIS.(Online). Diakses tanggal 22 desember 2014 diperoleh dari http://news.metrotvnews.com

Usman, I. (2013). Kepribadian, komunikasi, kelompok teman sebaya, iklim sekolah dan perilaku bullying. Jurnal Humanitas, 10, 1.

Walgito, B. (2003). Psikologi Sosial: Suatu Pengantar. Yogyakarta: Penerbit Andi 
UNISIA, Vol. XXXVII No. 82 Januari 2015

Website Inklusif. (2012) Khusus Bukan Berbeda, Tak Bisa Dipaksakan Sama. (Online). Diakses Tanggal 08 Desember 2014 diperoleh dari http://pokja inklusifkalsel.org/berita/detail/57

Web.KPAI. (2014).KPAI: kasus bullying dan pendidikan karakter.(Online). Diakses tanggal 22 desember 2014 diperoleh dari http://www.kpai.go.id/berita/kpai-kasus-bullying-danpendidkan-karakter

Widiharto, C.A.,Sandjaja, S.S., \& Eriany. P (2012).Perilaku bullying ditinjau dari harga diri dan pemahaman moral anak.IKIP PGRI Semarang. Semarang

Wiyani, N.A. (2012). Seve our children from school bullying. Yogyakarta: Ar-ruzz media

Woodcock, S., Hemmings, B., \& Kay, R. (2012). Does study of an inclusive education subject influence pre-service teachers concern and self-efficacy about inclusion?.Australia Journal Of Teacher Education, 37, 6.

Yuniardi, M.S. (2011). Inclusive Educarion Focused On Resiliency. LPSP3 UI. 